Professor Dorel-Mihai PARASCHIV, PhD (Corresponding author)

E-mail: dorel.paraschiv@ase.ro

International Business and Economics Department

The Bucharest University of Economic Studies

Professor Emilia ȚIȚAN, PhD

E-mail: emilia.titan@csie.ase.ro

Statistics and Econometrics Department

The Bucharest University of Economic Studies

Professor Daniela-Ioana MANEA, PhD

E-mail: daniela.manea@csie.ase.ro

Statistics and Econometrics Department

Carmen-Elena BĂNESCU, PhD Student

E-mail: bănescucarmen15@stud.ase.ro

The Bucharest University of Economic Studies

\title{
QUANTIFYING THE EFFECTS OF WORKING FROM HOME ON PRIVACY. AN EMPIRICAL ANALYSIS IN THE 2020 PANDEMIC
}

Abstract. In the article, we will present the impact of the COVID-19 pandemic on the balance between personal life and work at home for 23 European countries. Working from home is the only way for employees to be safe in terms of physical health. Beyond physical health, emotional state is essential for work-life balance. The research aims to highlight the main factors that describe work from home in the context of the COVID-19 pandemic.

The data used are taken from the website of the European Foundation for the Improvement of Living and Working Conditions, from the results of the survey, conducted in two stages, between April-May 2020, respectively June-July 2020. To identify the significant factors that describe life for employees working from home, the main component analysis was used based on the selected variables. The main components identified are used in a linear regression model to highlight the relationship between the overall satisfaction of working at home and its negative aspects.

The results obtained indicate two levels of negative factors that influence work from home: the common problems that employees had when working from home and those that arose because of COVID-19 pandemic. Apparently, the satisfaction of working from home is negatively influenced by the common problems that employees have when conducting their professional activities in this system. Being a period with a greater psycho-emotional impact on employees, the difficulties they had before working from home were much more accentuated and more visible. Therefore, it is recommended that employers do not put even more pressure on employees, who are overwhelmed by the new way of working. analysis.

Keywords: telework, COVID-19, labour market, work-life balance, multivariate

JEL Classification: C38, J22, J28, J81, O30

DOI: $10.24818 / 18423264 / 55.4 .21 .02$ 


\section{Introduction}

The year 2020 was challenging both from a health perspective and from an economic and social perspective. The onset of the COVID-19 pandemic highlighted the weaknesses of European states, regardless of their nature. The less developed countries were affected from an economic perspective because the lockdown period was a cessation of activity for many economic branches. The direct consequence of this global decision has also dramatically affected the labour market for some industrial sectors. However, also economic sectors continued their activity, in some cases, even with higher productivity, with employees in the "work from home" program. It is true that some countries have not been prepared in terms of digitalisation to operate remotely. At this point the limitations of the technological infrastructure for each economic entity intervene, but also those imposed by the skills of staff who can use these technologies.

The digital economy offered employees the opportunity to work remotely, the concept of teleworking or telecommuting being first used by Jack Nilles and spread by Francis Kinsman in the book "The Telecommuters" (1987). Due to the pandemic, in 2020, work from home was encouraged, this way of conducting professional activities having both advantages and disadvantages. In the paper we will assess the main factors that influence the quality of life of employees who worked from home with the establishment of restrictions generated by the pandemic. The study also identifies the impact of these factors on overall job satisfaction.

A first stage of the research consists, on the one hand in the study of the specialized literature, and on the other hand, in the identification of the results of some qualitative and quantitative analysis conducted in the field. The methodology required for the study includes methods of multivariate data analysis such as principal component analysis and linear regression. Following the interpretation of the results obtained, in addition to the conclusions and recommendations described regarding the benefits and disadvantages for employees working from home, we will also expose the limitations of this study. All these studies will give us the opportunity to introduce, in future analysis, new indicators that can optimise research.

\section{Review of the scientific literature}

Teleworking is a widespread concept in the global labour market, which has favoured the development of economic activities. Teleworking is a way to fulfil your job responsibilities from anywhere and anytime, giving the employee more flexibility (Sostero et al., 2020). This digital transformation of the labour market has allowed the business to continue in the lockdown period and in the immediate aftermath. According to a survey conducted by Eurofund in 2015, it was 
Quantifying the Effects of Working from Home on Privacy. An Empirical Analysis in the 2020 Pandemic

shown that the main determinants of distance work are "self-employment", higher education, occupations that do not involve manual activities, especially higher level (López-Igual and Rodríguez-Modroño, 2020). However, there are states like Japan where teleworking is only an alternative to social distancing (Kawashima et al., 2020).

People's choices regarding the choice of a job are based on the principle of maximizing income, to create better living conditions. During the pandemic, the order of priorities was slightly changed, so that one of the main options was to perform professional activities at home to reduce the risk of infection (Aum et al., 2021). Working from home has an important impact on the social life of the employee, who carry out their professional and personal activities, practically in the same place. However, it is not about this spatial inconvenience, but about the challenges brought to mental health (World Economic Forum, 2020). The employee, like any social being, can have several roles, which at some point interfere generating various conflicts (Biddle, 2013). One study shows that under normal conditions, people with fewer roles are more likely to be offered the opportunity to work from home (Zhang et al., 2020). In the context of the pandemic, working from home is mandatory, regardless of other characteristics. Thus, noncompliance with the boundaries between work and personal life can affect the employee's life balance (Palumbo, 2020).

Employers predicted a decrease in employee labour productivity, due to the multiple roles that employees have, but also due to the stress caused by the pandemic (World Economic Forum, 2020). In reality, the COVID-19 pandemic has led to an increase in the working day for employees working at home (Spurka and Straub, 2020). This can be positive if we consider that employees use more intensively the tools offered by information and communication technology (Nagel, 2020). The accidental appearance of the pandemic favored a forced digital transformation that led to a flexibility of the work schedule but also to some less pleasant aspects, if we refer to telemedicine and the doctor-patient relationship (Hollander and Carr, 2020; Faraj et al., 2021). However, job satisfaction of those who work from home does not differ significantly from that of those who continue to go to work (Nagel, 2020). It is true that in some cases, working from home has been more productive, but this should not lead employers to make hasty decisions and consider that the benefits of the lockdown can be replicated under any circumstances (Anderson and Kelliher, 2020).

However, employee well-being is correlated with job satisfaction, regardless of the environment in which you work (Sonnentag et al., 2017) but also with fatigue accumulated by prolonging the work schedule or due to distractions (Weigelt et al., 2021; Elfering et al., 2021). 


\section{Research methodology}

The data used to conduct the study are represented by the results of a survey conducted in 27 European countries by the European Foundation for the Improvement of Working and Living Conditions. The statistical research was conducted in two stages, in correlation with the types of restrictions generated by the prevention measures regarding the limitation of the spread of COVID infection - 19, during April-May 2020, respectively, June-July 2020. To sketch a more accurate picture of reality, only the states for which the dataset was complete were selected in the analysis. Thus, we will include in the analysis 8 variables that quantify the targeted issues for 23 European countries. For the Analysis in Main Components 7 of them will be used (Table 1), and for performing the regression analysis, we will consider the share of people who are satisfied with the development of professional activities in telework system, data processing being performed using SPSS (Version 26).

The main purpose of the study is to outline the effects of homework on an employee's life during the pandemic. We want to see what are the main factors that significantly influence employee satisfaction generated by working from home during the lockdown period. In this sense, we consider it necessary reducing the dimensionality of the set of indicators included in the analysis by applying the Principal Components Analysis (PCA). Thus, by determining the optimal number of principal components, with superunit attached eigenvalue, which have a relevant explanatory power (Finchilescu \& Muthal, 2019), we manage to concatenate the maximum information through a simple linear combination of the 7 initial variables. This indicates that the newly created variable brings the specific amount of information on at least one of the initial variables. The characteristics of the principal components can be identified by determining the correlation matrix between each component and the initial variables, and the variable that determines the component is the one for which the correlation coefficient has the highest value. Moreover, individual observations can also be represented graphically in the space of the components to understand which are the characteristics they benefit from (Boboc, 2007).

The individual scores obtained from the analysis in principal components continue to serve as explanatory variables in our approach to identify the factors that influence employee satisfaction for pandemic work from home. The benefit of an PCA applied before a multiple regression is to avoid multicollinearity, because the resulting principal components are independent and uncorrelated (Boboc, 2007).

Research hypotheses:

- Hypothesis \#1 Overall satisfaction with working from home is negatively influenced by the difficulties encountered by employees in carrying it out;

- Hypothesis \#2 The influence of the technological infrastructure that employees have on the way of working and the volume of work; 
Quantifying the Effects of Working from Home on Privacy. An Empirical Analysis in the 2020 Pandemic

- Hypothesis \#3 The interdependence between the technical equipment adequate to perform professional activities at home and the degree of concern and exhaustion generated by the job.

\section{Results and discussion}

The study includes variables based on the results of the survey "Living, working and COVID-19 in April 2020" (Eurofound, 2020). Based on the respondents' answers aspects related to the quality of life and economic well-being are analysed, as well as the existence of a balance between professional and personal life in the conditions of performing the activity in the telework system. The prolongation of the crisis, generated by the COVID-19 pandemic, determined the development of the survey in several phases, so that the results obtained from the analysis of the answers lead to the development of strategies and policies to reduce its negative effects. The first phase was launched in early April 2020, a period considered the beginning of the first economic deadlock for most EU Member States. In July 2020, as the number of cases decreased, the possibility of reopening savings led to the addition of additional questions on the use of online services, online schooling, quality and safety at work. However, it was wanted to obtain information on how to provide support, support from the government. The current situation - the economic blockages generated by the appearance of new strains of the virus, in the conditions of the development of vaccination programs required the conduct of the third phase of the survey (starting February 15). In this context, the authors' intention is to highlight the factors that influence employee satisfaction for work from home.

The variables included in the analysis describe the main possible issues that employees faced during the lockdown period. Most likely, for some employees new things appeared in the activity such as involuntary increase in work schedule, difficulty concentrating, exhaustion due to increasing activities and lack of opportunities for relaxation, which can change both their quality of life but and the quality of professional activities. Considering that employees working for the first time in the telework system behave differently from those who have conducted their activities in this way, another variable included in this study will consider the share of employees who started working from home with the onset of the pandemic (on average $36.9 \%$ in Europe). If initially we could consider digitalization as one of the premises for the emergence of the concept of remote work (Stacey et al., 2018), by facilitating professional activities in a comfortable environment and with a flexible schedule, now it is an essential factor. The COVID-19 pandemic has accelerated this process, but in addition to updating and adapting companies' procedures and policies related to telework (Sorensen et al., 2021), the existence of a digital infrastructure that allows employees to do so is also required. Correlated with the fact that, on average, $66.67 \%$ of the respondents stated that they have the technical equipment necessary to work from home, which is a necessary condition 
to be able to perform their activities in the telework system, we can include in the analysis a variable regarding the share of employees who have at home a technical infrastructure necessary for their job (Table 1).

\section{Table 1. Description of variables included in the analysis}

V1 The share of employees who started working from home with the onset of the pandemic Share of people who agree with the volume of work that employers require of employees since the pandemic began

V3 The share of employees who have at home a technical infrastructure necessary for their job

V4 The share of people who worry about work-related activities even when they are not working

V5 Share of people who said they feel exhausted after work and can no longer perform family

tasks

V6 The share of people who stated that they could not concentrate on working from home due to family responsibilities

V7 The share of employees who had a longer work schedule than usual

Preliminary data analysis consists in standardizing the variables used and identifying statistically significant correlations between them (Table 2).

Table 2. Correlation Matrix

\begin{tabular}{|c|c|c|c|c|c|c|c|c|}
\hline \multicolumn{9}{|c|}{ Correlations } \\
\hline \multicolumn{2}{|c|}{ Spearman's rho } & V1 & V2 & V3 & $\mathrm{V4}$ & V5 & V6 & V7 \\
\hline \multirow{3}{*}{ V1 } & Correlation Coefficient & 1.000 & .211 & $.458^{*}$ & -.297 & -.295 & .092 & $.555^{* *}$ \\
\hline & Sig. (2-tailed) & & .335 & .028 & .168 & .171 & .676 & .006 \\
\hline & $\mathrm{N}$ & 23 & 23 & 23 & 23 & 23 & 23 & 23 \\
\hline \multirow{3}{*}{ V2 } & Correlation Coefficient & .211 & 1.000 & $.573^{* * *}$ & $-.470^{*}$ & $-.603^{* *}$ & -.324 & .161 \\
\hline & Sig. (2-tailed) & .335 & & .004 & .023 & .002 & .132 & .462 \\
\hline & $\mathrm{N}$ & 23 & 23 & 23 & 23 & 23 & 23 & 23 \\
\hline \multirow{3}{*}{ V3 } & Correlation Coefficient & $.458^{*}$ & $.573^{* *}$ & 1.000 & $-.440^{*}$ & $-.546^{* * *}$ & -.271 & .106 \\
\hline & Sig. (2-tailed) & .028 & .004 & & .036 & .007 & .210 & .631 \\
\hline & $\mathrm{N}$ & 23 & 23 & 23 & 23 & 23 & 23 & 23 \\
\hline \multirow{3}{*}{ V4 } & Correlation Coefficient & -.297 & $-.470^{*}$ & $-.440^{*}$ & 1.000 & $.645^{* *}$ & $.462^{*}$ & .074 \\
\hline & Sig. (2-tailed) & .168 & .023 & .036 & & .001 & .026 & .738 \\
\hline & $\mathrm{N}$ & 23 & 23 & 23 & 23 & 23 & 23 & 23 \\
\hline \multirow{3}{*}{ V5 } & Correlation Coefficient & -.295 & $-.603^{* k}$ & $-.546^{k * 2}$ & $.645^{* *}$ & 1.000 & $.500^{*}$ & -.066 \\
\hline & Sig. (2-tailed) & .171 & .002 & .007 & .001 & & .015 & .766 \\
\hline & $\mathrm{N}$ & 23 & 23 & 23 & 23 & 23 & 23 & 23 \\
\hline \multirow{3}{*}{ V6 } & Correlation Coefficient & .092 & -.324 & -.271 & $.462^{*}$ & $.500^{*}$ & 1.000 & .254 \\
\hline & Sig. (2-tailed) & .676 & .132 & .210 & .026 & .015 & & .242 \\
\hline & $\mathrm{N}$ & 23 & 23 & 23 & 23 & 23 & 23 & 23 \\
\hline \multirow{3}{*}{ V7 } & Correlation Coefficient & $.555^{* *}$ & .161 & .106 & .074 & -.066 & .254 & 1.000 \\
\hline & Sig. (2-tailed) & .006 & .462 & .631 & .738 & .766 & .242 & \\
\hline & $\mathrm{N}$ & 23 & 23 & 23 & 23 & 23 & 23 & 23 \\
\hline
\end{tabular}

To reduce the dimensionality, the Principal Components Analysis (PCA) is performed, from which we will extract the relevant factors used later to highlight the impact that the analysed variables have on the satisfaction of working at home. A preliminary step to the Principal Component Analysis includes assessing the adequacy of sampling to obtain a reliable result using Kaiser-Meyer-Olking 
Quantifying the Effects of Working from Home on Privacy. An Empirical Analysis in the 2020 Pandemic

(KMO) statistics, as well as identifying appropriate correlations between variables using the Bartlett test (Table 3).

The results obtained $(K M O=0.649>0.6$ and Sig. $=0.001<0.05)$ indicate a good adequacy of the sampling and the fact that the correlation matrix is not an identity matrix, thus meeting the minimum conditions to perform an PCA on the data set.

Table 3. Total Variance Explained

\begin{tabular}{ccc} 
Kaiser-Meyer-Olkin Measure of Sampling Adequacy. & .649 \\
\hline Bartlett's Test of Sphericity & Approx. Chi-Square & 46.336 \\
\cline { 2 - 3 } & df & 21 \\
\cline { 2 - 3 } & Sig. & .001 \\
\hline
\end{tabular}

To identify the main components, which represent linear combinations of the original variables included in the analysis, we will identify the factors with the superunit eigenvalues (Table 4).

Table 4. Total Variance Explained

\begin{tabular}{|c|c|c|c|c|c|c|c|c|c|}
\hline \multirow[b]{2}{*}{ Component } & \multicolumn{3}{|c|}{ Initial Eigenvalues } & \multicolumn{3}{|c|}{$\begin{array}{l}\text { Extraction Sums of Squared } \\
\text { Loadings }\end{array}$} & \multicolumn{3}{|c|}{$\begin{array}{l}\text { Rotation Sums of Squared } \\
\text { Loadings }\end{array}$} \\
\hline & Total & $\begin{array}{c}\% \text { of } \\
\text { Variance }\end{array}$ & $\begin{array}{c}\text { Cumulative } \\
\%\end{array}$ & Total & $\begin{array}{c}\% \text { of } \\
\text { Variance }\end{array}$ & $\begin{array}{c}\text { Cumulative } \\
\%\end{array}$ & Total & $\begin{array}{c}\% \text { of } \\
\text { Variance }\end{array}$ & $\begin{array}{c}\text { Cumulative } \\
\%\end{array}$ \\
\hline 1 & 2.810 & 40.137 & 40.137 & 2.810 & 40.137 & 40.137 & 2.782 & 39.740 & 39.740 \\
\hline 2 & 1.755 & 25.067 & 65.204 & 1.755 & 25.067 & 65.204 & 1.782 & 25.464 & 65.204 \\
\hline 3 & .780 & 11.146 & 76.350 & & & & & & \\
\hline 4 & .671 & 9.579 & 85.929 & & & & & & \\
\hline 5 & .394 & 5.628 & 91.557 & & & & & & \\
\hline 6 & .353 & 5.038 & 96.595 & & & & & & \\
\hline 7 & .238 & 3.405 & 100.000 & & & & & & \\
\hline
\end{tabular}

The first two components synthesise approximately $65.20 \%$ of the total variance, in the theoretical hypothesis that assumes that the variables are measured without errors, so there is no residual variance. Thus, the first main component retains $40.14 \%$ of the variation of the initial variables, which means the information brought by almost 3 variables, while the second main component brings an additional $25.07 \%$ of the variation of the initial variables, i.e., the information of almost 2 variables (Table 4).

The graphical representation of the components validates the previously exposed results, presenting the own value of each component. We observe an inflection point (elbow) at the third component, which means that the following components explain smaller and smaller quantities of the total variance (Figure 1). 


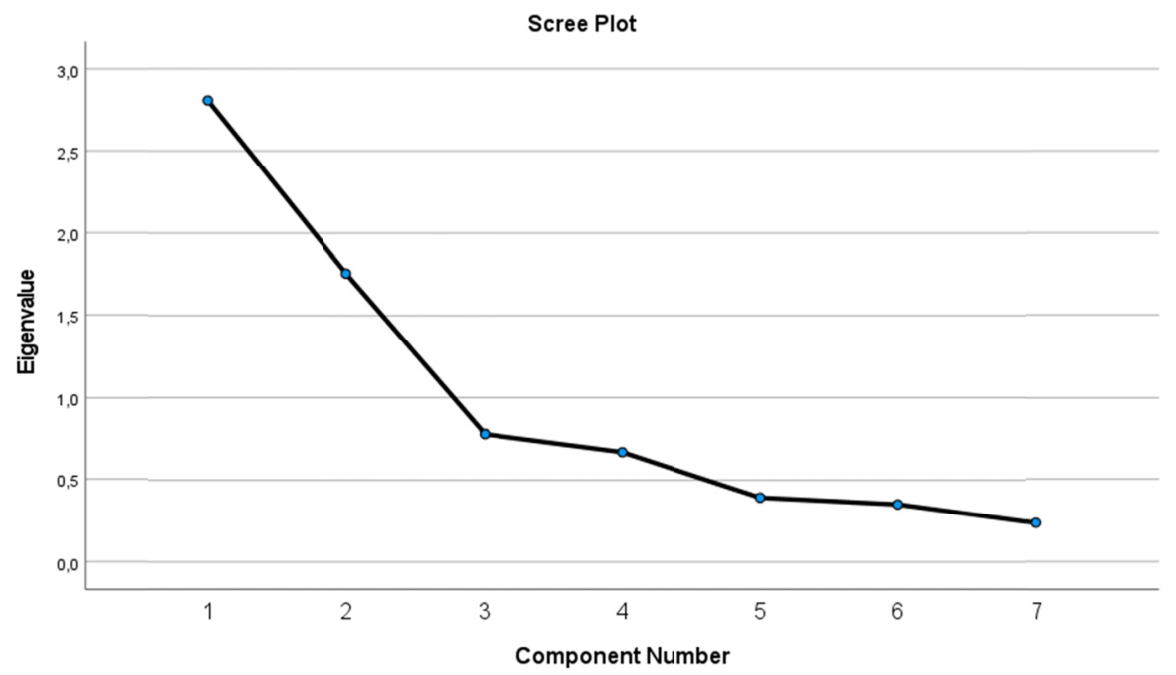

Figure 1. Component Scree Plot

Depending on the saturation values corresponding to each variable, after rotating the factors, the indicators that form the two components that describe the problems faced by employees working from home (Component 1$)$ and the specific ones generated by the pandemic (Component2) are identified.

Table 5. Identification of components, after rotation of factors

\begin{tabular}{|c|c|c|c|}
\hline Component & Variables & Saturation & $\begin{array}{l}\text { Component } \\
\text { identification }\end{array}$ \\
\hline \multirow{5}{*}{1} & $\begin{array}{l}\text { V2 Share of people who agree with the volume } \\
\text { of work that employers require of employees } \\
\text { since the pandemic began }\end{array}$ & -0.664 & \multirow{5}{*}{$\begin{array}{l}\text { General problems } \\
\text { faced by employees } \\
\text { working from home }\end{array}$} \\
\hline & $\begin{array}{l}\text { V3 The share of employees who have at home a } \\
\text { technical infrastructure necessary for their job }\end{array}$ & -0.717 & \\
\hline & $\begin{array}{l}\text { V4 The share of people who worry about work- } \\
\text { related activities even when they are not } \\
\text { working }\end{array}$ & 0.779 & \\
\hline & $\begin{array}{l}\text { V5 Share of people who said they feel } \\
\text { exhausted after work and can no longer perform } \\
\text { family tasks }\end{array}$ & 0.827 & \\
\hline & $\begin{array}{l}\text { V6 The share of people who stated that they } \\
\text { could not concentrate on working from home } \\
\text { due to family responsibilities }\end{array}$ & 0.648 & \\
\hline \multirow[t]{2}{*}{2} & $\begin{array}{l}\text { V1 The share of employees who started } \\
\text { working from home with the onset of the } \\
\text { pandemic }\end{array}$ & 0.762 & \multirow{2}{*}{$\begin{array}{l}\text { The problems of } \\
\text { working from home } \\
\text { that employees } \\
\text { faced during the } \\
\text { pandemic }\end{array}$} \\
\hline & $\begin{array}{l}\text { V7 The share of employees who had a longer } \\
\text { work schedule than usual }\end{array}$ & 0.802 & \\
\hline
\end{tabular}


Quantifying the Effects of Working from Home on Privacy. An Empirical Analysis in the 2020 Pandemic

The first principal component identifies the general problems faced by employees who work from home, this being strongly correlated, in a positive sense, with the share of people who worry about professional activities even when not working, of those who consider they are exhausted after work and they can no longer perform their family tasks but also those who cannot concentrate on working from home due to family responsibilities (Hypothesis \# 3). An adequate technical infrastructure for teleworking and agreeing on a workload with employers are elements that are inversely correlated with the first component.

The second main component, which explains $25.46 \%$ of the variance of the included variables (Table 4), is positively correlated with the share of people who started working from home with the pandemic and those who stated that they work more than before the pandemic. Thus, we can consider that this component indicates the problems faced by employees, generated by conducting professional activities at home, during the pandemic.

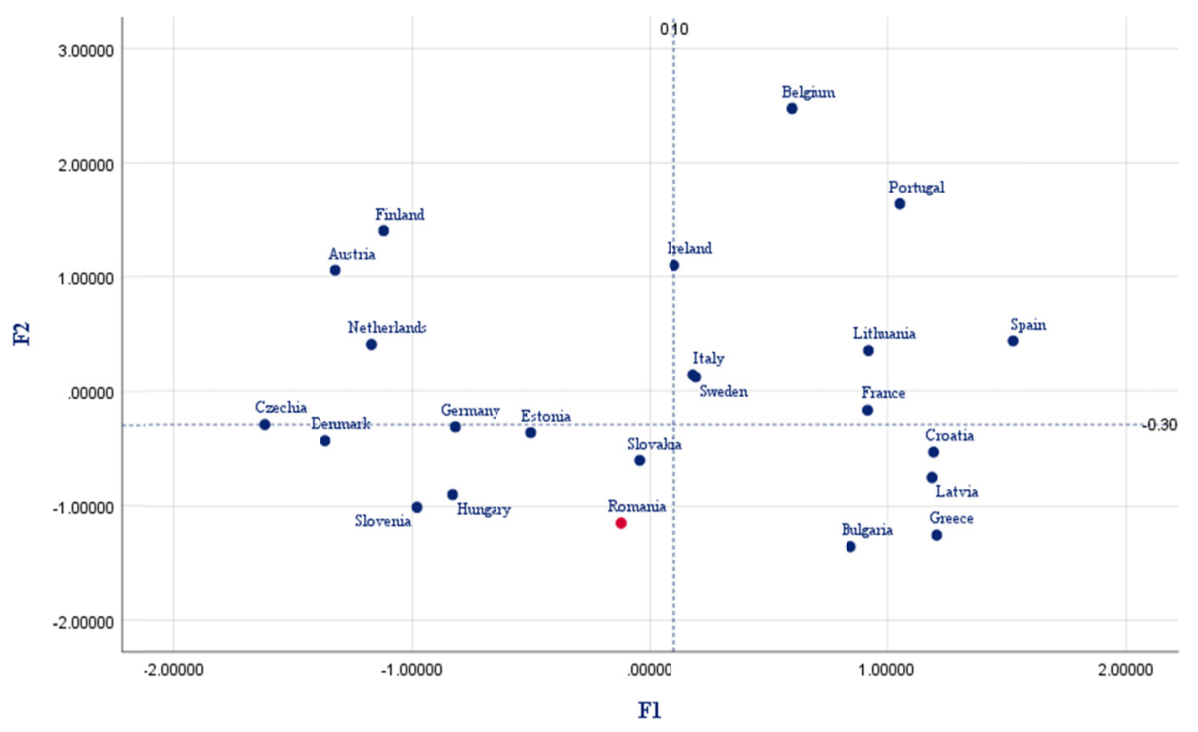

Figure 2. Projection of the variable in the space of the main components

An increased heterogeneity of the distribution of states can be observed, fact for which the states whose projection exceeds the interval $[-1 ;+1]$ are considered extreme values. Ireland is a state where the share of employees affected by work from home is extremely high, with Romania at the opposite pole. In Lithuania and France, the pandemic intensified work from home where possible, but the share of those who worked more increased above average. The Netherlands and Germany are countries where the share of those who started working from 
home because of the outbreak of the pandemic is below average. Moreover, in these two states there was no change in the number of hours worked.

However, the difficulty of maintaining a work-life balance is not a new issue. This problem affects both employees and employers to the same extent, and one of the determining factors, the extended work schedule, is accentuated during the pandemic. Increasing the share of people working in telework and ICT-based mobile work (TICTM) requires updating the national and international legislation in the field, but also the methodologies and regulations of each company. A good digital infrastructure and the flexibility of the work schedule, in the case of performing activities in the telework system can lead to the balance between professional and private life, provided that the work schedule agreed with the employer is respected. The Eurofound report (2020a) provides an overview of the highest level of regulations linking ICTM and work-life balance (Figure 3).

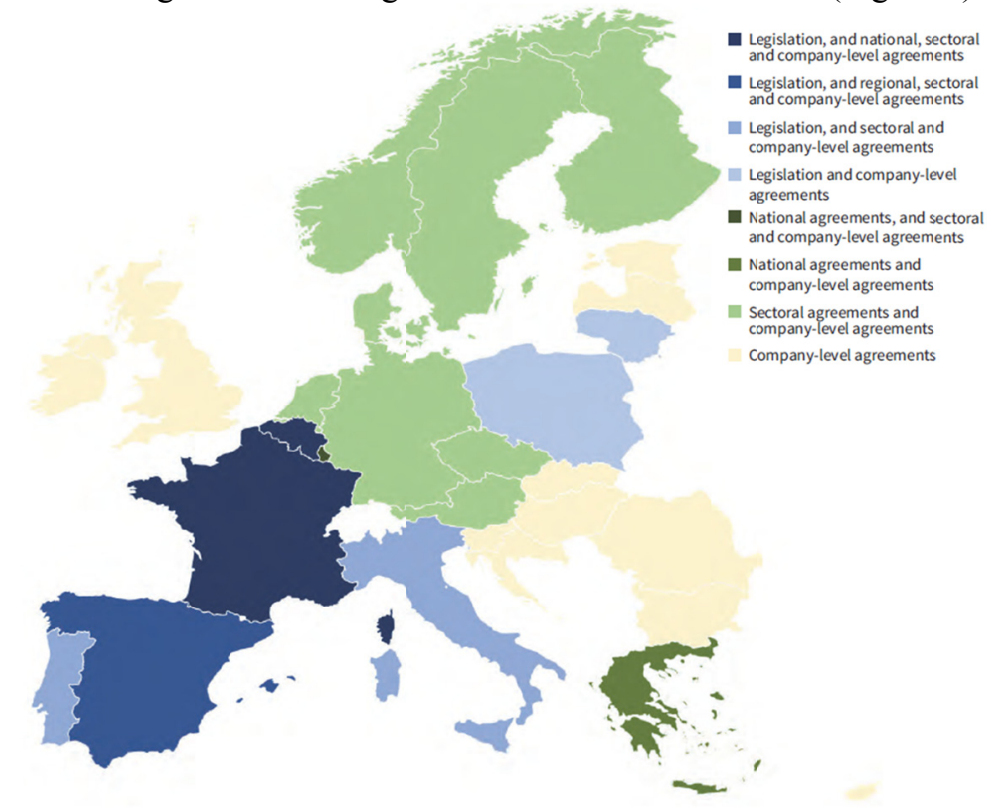

Figure 3. Legislation and agreements linking TICTM and work-life balance Source: Eurofound (2020a), Regulations to address work-life balance in digital flexible working arrangements, p. 12

Currently, most EU countries have legislation regulating how teleworking is conducted, but they may have specific regulations regarding the use of ICT. To cover these legislative gaps, in countries where there is no such legislation, one of the solutions is regulated by collective agreements at the level of each entity. Thus, in the Nordic countries (Denmark, Finland, Sweden and Norway) there are collective agreements in this field, in Ireland they support teleworking, especially 
Quantifying the Effects of Working from Home on Privacy. An Empirical Analysis in the 2020 Pandemic

in terms of the positive impact it can have on work-life balance (Eurofounnd, 2020a).

In countries such as Belgium, France, Italy, Spain, legislative provisions on the general and specific conditions of telework are developed in the agreements at the level of each sector of activity, respectively, at the level of companies.

The Employers' Federation of Financial Services in Romania, together with the unions in the industrial sectors in Romania, negotiated a collective agreement at the sectoral level for financial and insurance activities that regulate the development of professional activity in teleworking (2018), including the fact that any activity outside the programme work agreed with the employer leads to overtime.

The determined principal components (F1 and F2) are used to identify the dependence between the general satisfaction offered by telework (V8 - The share of people who are satisfied with the professional activities in the telework system) and the problems generated by it. Correlation and regression analysis is used to highlight existing links.

Table 6. Correlations between overall job satisfaction and PCA factors

\begin{tabular}{|c|c|c|c|c|}
\hline & & V8 & F1 & $\mathrm{F} 2$ \\
\hline \multirow{3}{*}{$\begin{array}{l}\text { V8 - Share of people who are satisfied with the } \\
\text { development of professional activities in the } \\
\text { telework system }\end{array}$} & Pearson Correlation & 1 & $-.789^{* *}$ & .265 \\
\hline & Sig. (2-tailed) & & .000 & .223 \\
\hline & $\mathrm{N}$ & 23 & 23 & 23 \\
\hline \multirow{3}{*}{$\begin{array}{l}\text { F1 - General problems faced by employees } \\
\text { working from home }\end{array}$} & Pearson Correlation & $-.789^{* *}$ & 1 & .000 \\
\hline & Sig. (2-tailed) & .000 & & 1.000 \\
\hline & $\mathrm{N}$ & 23 & 23 & 23 \\
\hline \multirow{3}{*}{$\begin{array}{l}\text { F2 - The problems of working from home that } \\
\text { employees faced during the pandemic }\end{array}$} & Pearson Correlation & .265 & .000 & 1 \\
\hline & Sig. (2-tailed) & .223 & 1.000 & \\
\hline & $\mathrm{N}$ & 23 & 23 & 23 \\
\hline
\end{tabular}

**. Correlation is significant at the 0.01 level (2-tailed).

The correlation analysis performed (Table 6) identifies a significant and inverse link between the share of people who are satisfied with the performance of professional activities in the telework system (V8) and the component that summarizes the general problems faced by employees working in this system (F1). 


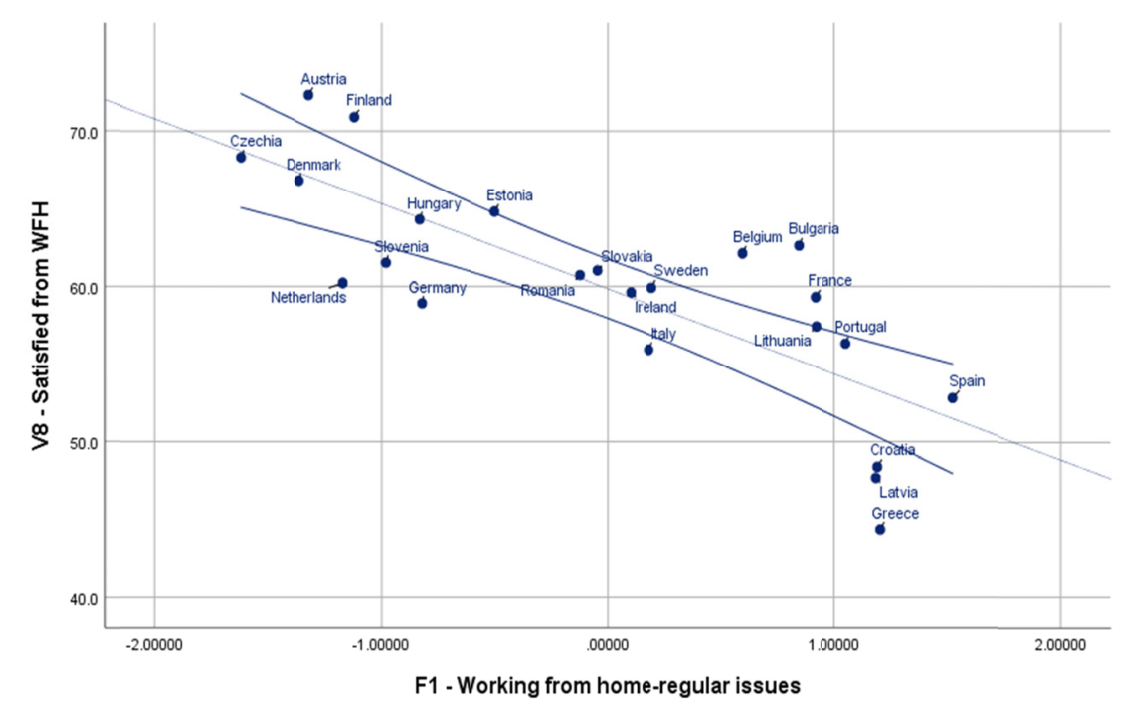

Figure 4. The correlation between the general satisfaction offered by telework (V8) and the problems generated by it (F1)

The positioning of the EU states included in the analysis in relation to the correlation between the two variables is reflected in Figure 4, observing a linear dependence between the satisfaction offered by work at home and the identified negative aspects.

Table 7. Tests of Normality

\begin{tabular}{|c|c|c|c|c|c|c|}
\hline & \multicolumn{3}{|c|}{ Kolmogorov-Smirnov ${ }^{\text {a }}$} & \multicolumn{3}{|c|}{ Shapiro-Wilk } \\
\hline & Statistic & df & Sig. & Statistic & df & Sig. \\
\hline $\begin{array}{l}\text { V8 - Share of people who are satisfied with the } \\
\text { development of professional activities in the } \\
\text { telework system }\end{array}$ & .142 & 23 & $.200^{*}$ & .963 & 23 & .519 \\
\hline $\begin{array}{l}\text { F1 - The problems of working from home that } \\
\text { employees faced during the pandemic }\end{array}$ & .148 & 23 & $.200^{*}$ & .925 & 23 & .084 \\
\hline
\end{tabular}

For the two variables retained in the analysis, normality was tested (Table 7) to construct the regression model.

To identify the impact generated by telework difficulties on the overall satisfaction of working from home, the regression model used can be written as follows:

$$
\widehat{V 8}=b_{0}+b_{1} \cdot F 1
$$

where,

$\widehat{V 8}$ represent share of people who are satisfied with the development of professional activities in the telework system - dependent variable; 
Quantifying the Effects of Working from Home on Privacy. An Empirical Analysis in the 2020 Pandemic

$F 1$ represent the problems of working from home that employees faced during the pandemic - independent variable;

$b_{0}, b_{1}$ represents the regression coefficients.

After estimating the model, the following results were obtained:

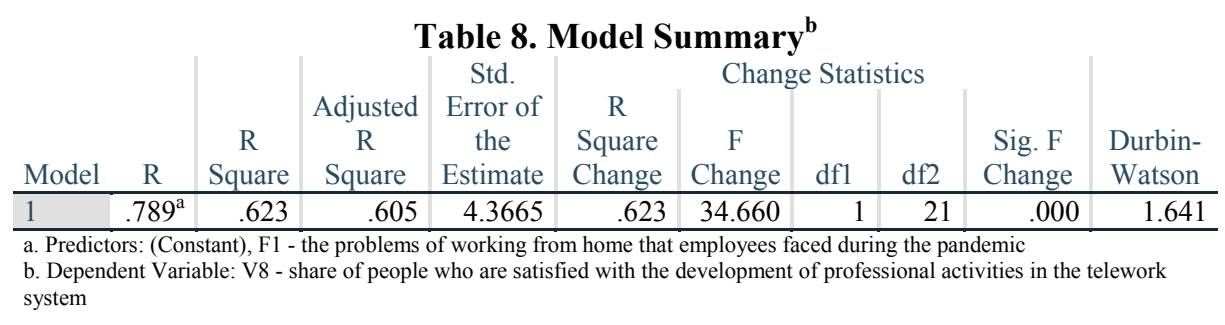

The proposed linear regression model verifies the validation hypotheses regarding errors, is statistically significant (Sig.F Change $=0.000<0.05)$ and explains $62.3 \%$ of the variation of the dependent variable (Table 8 ).

Table 9. Regression Coefficients ${ }^{\mathrm{a}}$

\begin{tabular}{|c|c|c|c|c|c|c|c|c|c|}
\hline \multirow[b]{3}{*}{ Model } & \multirow{2}{*}{\multicolumn{2}{|c|}{$\begin{array}{l}\text { Unstandardized } \\
\text { Coefficients }\end{array}$}} & & & & \\
\hline & & & \multirow{2}{*}{$\begin{array}{c}\text { Standardized } \\
\text { Coefficients } \\
\text { Beta }\end{array}$} & \multirow[b]{2}{*}{$\mathrm{t}$} & \multirow[t]{2}{*}{ Sig. } & \multicolumn{2}{|c|}{$\begin{array}{c}95.0 \% \\
\text { Confidence } \\
\text { Interval for B }\end{array}$} & \multicolumn{2}{|c|}{$\begin{array}{l}\text { Collinearity } \\
\text { Statistics }\end{array}$} \\
\hline & B & $\begin{array}{l}\text { Std. } \\
\text { Error }\end{array}$ & & & & $\begin{array}{l}\text { Lower } \\
\text { Bound }\end{array}$ & $\begin{array}{l}\text { Upper } \\
\text { Bound }\end{array}$ & Tolerance & VIF \\
\hline 1 (Constant) & 59.830 & .910 & & 65.713 & .000 & 57.937 & 61.724 & & \\
\hline F1 & -5.481 & .931 & -.789 & -5.887 & .000 & -7.417 & -3.545 & 1.000 & 1.000 \\
\hline
\end{tabular}

The regression model obtained $(\widehat{V 8}=59.830-5.481 \cdot F 1)$ confirms Hypothesis \#1 of the research according to which the general satisfaction for working from home is negatively influenced by the difficulties encountered by employees in its development. Both regression coefficients are statistically significant, the share of employees satisfied with working from home during the lockdown decreases by 5,481 percentage points, when the F1 component (General problems faced by employees working from home) increases by one unit.

\section{Conclusions}

As all studies conducted during this period show, teleworking influences the work-life balance in the 2020 pandemic in Europe. Conducting professional activity at home generates positive effects, in the sense of developing employees' digital skills but also of personal endowment with IT equipment appropriate to the profession. Also, research seeks to assess conflicts that have arisen due to the 
inability to firmly delimit the boundaries between work and personal life. Our interest focused on highlighting the factors that influence employee satisfaction for work from home, based on a set of variables to describe the opinion of employees on the effort involved in home work, all the collateral aspects that derive from it.

The described research hypotheses were analysed and validated, the general satisfaction for working from home being negatively influenced by the difficulties encountered by employees in its development, according to the regression model. From the perspective the influence generated by a good digital infrastructure, both employees and companies (Negrea, 2019), there is a direct link with an adequate way of performing activities in the telework system and with a decrease in the degree of concern and exhaustion, especially during the pandemic.

The results of the survey developed by Eurofound show that the European average of employees who were satisfied with working from home is $56.8 \%$. The fact that almost half of the participants in this study were not satisfied with this form of work is explained by several factors. Thus, we differentiated between two types of problems encountered in working from home: general problems specific to working from home and additional problems generated by the pandemic period. Simultaneously, research shows that working from home gives European employees additional responsibility for work-specific activities, diminishing their free time, as they become increasingly stressed and tired.

A limitation of the research can be considered the lack of inclusion in the analysis of indicators that quantify aspects of the culture of working from home among employees, as there is a greater concern for work than for privacy.

A future direction of research, will analyse the dependencies between the increase in the number of employees working in the telework system, labour productivity and their well-being.

\section{REFERENCES}

[1] Anderson, D. and Kelliher, C. (2020), Enforced Remote Working and the Work-Life Interface during Lockdown. Gender in Management: An International Journal. 35, pp. 677-683. https://doi.org/10.1108/GM-07-2020-0224; [2] Aum, S., Lee, S.Y.T. and Shin, Y. (2021), Inequality of Fear and Selfquarantine: Is there a Trade-off between GDP and Public Health?. Journal of Public Economics, 194, p.104354. https://doi.org/10.1016/j.jpubeco.2020.104354; [3] Biddle, J. B. (2013), Role Theory: Expectations, Identities, and Behaviors. New York: Academic Press;

[4] Boboc, C. (2007), Analiza statistică multidimensională. Aplicaţii în cadrul studiului produselor şi serviciilor. Bucureşti. Meteor Press;

[5] Elfering, A., Kottwitz, M.U. and Semmer, N.K. (2021), Battery Discharge from Monday to Friday: Background Social Stress at Work is Associated with more Rapid Accumulation of Fatigue. Sleep and Vigilance, pp.1-12. https://doi.org/10.1007/s41782-021-00127-7; 
Quantifying the Effects of Working from Home on Privacy. An Empirical Analysis in the 2020 Pandemic

[6] Eurofound, (2020), Living, working and COVID-19, COVID-19 series, Publications Office of the European Union, Luxembourg. https://www.eurofound.europa.eu/publications/report/2020/living-working-andcovid-19;

[7] Eurofound, (2020a), Regulations to address work-life balance in digital flexible working arrangements, New forms of employment series, Publications Office of the European Union, Luxembourg.

https://www.eurofound.europa.eu/publications/report/2020/regulations-to-addresswork-life-balance-in-digital-flexible-working-arrangements\#tab-01;

[8] Faraj, S., Renno, W. and Bhardwaj, A. (2021), Unto the Breach: What the COVID-19 Pandemic Exposes about Digitalization. Information and Organization, 31(1), p.100337. https://doi.org/10.1016/j.infoandorg.2021.100337; [9] Finchilescu, G. and Muthal, S. (2019), Q Methodology: Patterns of Subjectivity in Academic Misconduct. Transforming Research Methods in the Social Sciences. s.l.: Wits University Press, pp. 130-148;

[10] IBM Corp. Released 2019. IBM SPSS Statistics for Windows, Version 26.0. Armonk, NY: IBM Corp

[11] Hollander, J.E. and Carr, B.G. (2020), Virtually Perfect? Telemedicine for COVID-19. New England Journal of Medicine, 382(18), pp.1679-1681.

https://doi.org/10.1056/NEJMp2003539;

[12] Kawashima, T. et al. (2020), The Relationship between Fever Rate and Telework Implementation as a Social Distancing Measure against the COVID-19 Pandemic in Japan. [Online] Available at: https://doi.org/10.1016/j.puhe.2020.05.018;

[13] López-Igual, P. \& Rodríguez-Modroño, P. (2020), Who is Teleworking and Where from? Exploring the Main Determinants of Telework in Europe. Sustainability. https://doi.org/10.3390/su12218797;

[14] Mihai M. (2017), Metode statistice aplicate în studiul fenomenelor sociale; ASE Publishing, Colecția de Statistică și Econometrie, București, ISBN 978-60634-0207-4, 252 page;

[15] Mihaela, M. (2015), Education and Innovation... are they Relevant Processes in the Development of Social Inclusion Policies?. Procedia economics and finance, 23, pp.547-554. https://doi.org/10.1016/S2212-5671(15)00556-0;

[16] Nagel, L. (2020), The Influence of the COVID-19 Pandemic on the Digital Transformation of Work. International Journal of Sociology and Social Policy. Vol. 40 No. 9/10, pp. 861-875. https://doi.org/10.1108/IJSSP-07-2020-0323; [17] Negrea, A., Ciobanu, G., Dobrea, C. and Burcea, S. (2019), Priority Aspects in the Evolution of the Digital Economy for Building New Development Policies. Calitatea, 20(S2), pp.416-421. https://www.webofscience.com/wos/alldb/full-record/WOS:000461854800062; 
[18] Palumbo, R. (2020), Let me Go to the Office! An Investigation into the Side Effects of Working from Home on Work-life Balance. International Journal of Public Sector Management. Vol. 33 No. 6/7, pp. 771-790.

https://doi.org/10.1108/IJPSM-06-2020-0150;

[19] Sonnentag, S., Venz, L. and Casper, A. (2017), Advances in Recovery Research: What Have we Learned? What Should be Done Next?. Journal of Occupational Health Psychology, 22(3), p.365.https://doi.org/10.1037/ocp0000079

[20] Sorensen, G., Dennerlein, J.T., Peters, S.E., Sabbath, E.L., Kelly, E.L. and Wagner, G.R. (2021), The Future of Research on Work, Safety, Health and Wellbeing: A Guiding Conceptual Framework. Social Science \& Medicine, 269, p.113593.https://doi.org/10.1016/j.socscimed.2020.113593;

[21] Sostero, M., Milasi, S., Hurley, J., Fernandez-Macias, E. and Bisello, M. (2020), Teleworkability and the COVID-19 Crisis: A New Digital Divide?.

European Commission. JRC121193;

[22] Spurka, D. and Straub, C. (2020), Flexible Employment Relationships and Careers in Times of the COVID-19 Pandemic. Journal of Vocational Behavior, p. 119. https://doi.org/10.1016/j.jvb.2020.103435;

[23] Stacey, N., Ellwood, P., Bradbrook, S., Reynolds, J., Williams, H. and Lye, D. (2018), Foresight on New and Emerging Occupational Safety and Health Risks Associated with Digitalisation by 2025. European Agency for Safety and Health at Work, Publications Office of the European Union: Luxembourg; [24] Voineagu, V. et al. (2007), Teorie și practică econometrică. București: Meteor Press;

[25] World Economic Forum, (2020), The Future of Jobs Report 2020. World Economic Forum, Geneva, Switzerland.https://www.weforum.org/reports/thefuture-of-jobs-report-2020;

[26] Zhang, S., Moeckel, R., Moreno, A.T., Shuai, B. and Gao, J. (2020), $A$ Work-life Conflict Perspective on Telework. Transportation Research Part A: Policy and Practice, 141, pp.51-68.https://doi.org/10.1016/j.tra.2020.09.007;

[27] Weigelt, O., Siestrup, K. and Prem, R. (2021), Continuity in TransitionCombining Recovery and Day-of-Week Perspectives to Understand Changes in Employee Energy across the Seven-day week. Journal of Organizational Behavior. https://doi.org/10.1002/job.2514. 